\title{
INBREEDING AND THERMAL ADAPTATION IN DROSOPHILA SUBOBSCURA
}

\begin{tabular}{|r|l|}
\hline Journal: & Genome \\
\hline Manuscript ID: & gen-2014-0149.R1 \\
\hline Manuscript Type: & Article \\
\hline Date Submitted by the Author: & n/a \\
\hline Complete List of Authors: & $\begin{array}{l}\text { Zivanovic, Goran; University of Belgrade, Genetics } \\
\text { Arenas, Conxita; Universitat de Barcelona, Estadística } \\
\text { Mestres, Francisco; Universitat de Barcelona, Spain, Genètica }\end{array}$ \\
\hline Keyword: & $\begin{array}{l}\text { Drosophila subobscura, inbreeding, chromosomal inversions, thermal } \\
\text { adaptation, fertility }\end{array}$ \\
\hline
\end{tabular}

\section{SCHOLARONE ${ }^{\text {m }}$ \\ Manuscripts}




\section{INBREEDING AND THERMAL ADAPTATION IN DROSOPHILA}

\section{SUBOBSCURA}

3

4 Goran Zivanovic ${ }^{1}$, Conxita Arenas ${ }^{2}$ and Francesc Mestres ${ }^{3}$

5

$6{ }^{1}$ Department of Genetics, Institute for Biological Research "Sinisa Stankovic".

7 University of Belgrade, Serbia.

$8 \quad{ }^{2}$ Departament d'Estadística, Universitat de Barcelona, Barcelona, Spain.

$9{ }^{3}$ Departament de Genètica, Universitat de Barcelona, Barcelona, Spain.

11 Corresponding author:

12 Goran Zivanovic

13 Department of Genetics, Institute for Biological Research "Sinisa Stankovic",

14 University of Belgrade, Bulevar Despota Stefana 142, 11000 Belgrade, Serbia

15

16 Phone: (38111) 2764422

17 FAX: (38111) 2761433

18 E-mail: goranziv@ibiss.bg.ac.rs

19

20 Running title: Inbreeding and thermal adaptation 
22 Abstract: Using a well-adapted Drosophila subobscura population (Avala, Serbia), a

23 drastic experiment of inbreeding was carried out to assess whether the expected level of

24 homozygosity could be reached, or other evolutionary forces affected also the process.

25 In general, no significant changes of inversion (or arrangement) frequencies were

26 detected after twelve brother-sister mating generations. Furthermore, no significant

27 differences were obtained between observed and expected (under the inbreeding model)

28 karyotypic frequencies. Thus, these results seemed to indicate that the main

29 evolutionary factor in the experiment was inbreeding. However, in $\mathrm{G}_{12}$ generation

30 complete chromosomal fixation was reached only in two out of the eight final inbred

31 lines. In these lines, the chromosomal compositions were difficult to interpret, but could

32 be likely a consequence of adaptation to particular laboratory conditions (constant $18^{\circ} \mathrm{C}$,

33 food, light period, etc.). Finally in a second experiment, the inbred lines presented

34 higher fertility at $18^{\circ} \mathrm{C}$ than at $13^{\circ} \mathrm{C}$. Also, there was a significant line effect on fertility:

35 inbred line number $6\left(\mathrm{~A}_{1}, \mathrm{~J}_{1}, \mathrm{U}_{\underline{1+2}} ; \mathrm{U}_{\underline{1+2+6}}, \mathrm{E}_{8}\right.$ and $\left.\mathrm{O}_{\underline{3+4}+\underline{7}}\right)$ presented the higher values

36 and maybe it was the result of an adaptation to laboratory environment. Thus, the results

37 obtained in our experiments reflect the adaptive potential of $D$. subobscura inversions.

Key words: Drosophila subobscura, inbreeding, chromosomal inversions, thermal

40 adaptation, fertility. 


\section{Introduction}

Drosophila subobscura is a model species with a rich chromosomal polymorphism in most of its chromosomes: A (=X, the sex chromosome), E, J, O and U (Krimbas 1992, 1993; Powell 1997). It is generally accepted that this polymorphism is adaptive due to its geographic distribution pattern, although other explanations as historic factors could be also important (Krimbas and Loukas 1980; Sperlich and Pfriem 1986). The latitudinal clinal distribution of chromosomal inversions, both in North and South America, presenting the same pattern found in the Palearctic region was key evidence supporting their adaptive role (Prevosti et al. 1988, 1990; Menozzi and Krimbas 1992; Balanyà et al. 2003). Also, there are other observations supporting the adaptive role of inversions, for instance, their seasonal variation (Fontdevila et al. 1983; Rodriguez-Trelles et al. 1996; Zivanovic and Mestres 2010b) and long-term changes (Orengo and Prevosti 1996; Rodríguez-Trelles and Rodríguez 1998; Solé et al. 2002; Balanyà et al. 2004, 2006, 2009; Zivanovic and Mestres 2010a, 2011; Zivanovic et al. 2012), suggesting a response to climatic changes. Furthermore, in American populations of D. subobscura, the effect of selection has been measured in two chromosomal arrangements, $\mathrm{O}_{5}$ and $\mathrm{O}_{\underline{3+4}+\underline{7}}$ (Mestres et al. 2001). Although strong gene flow has been observed between natural populations of D. subobscura (Latorre et al. 1992; Pascual et al. 2001; Zivanovic et al. 2007; Araúz et al. 2009; Pegueroles et al. 2013), natural selection acting on inversions is able to maintain their geographical differentiation. This system of overlapped and non-overlapped inversions is a cornerstone of the adaptive and evolutionary potential of D. subobscura. One way to analyze this genomic architecture based on inversion is to disturb it, for example, by means of inbreeding experiments. In this species, the effect of inbreeding have been used to study the rate of development and fertility (Hollingsworth and Maynard Smith 1955), the pattern of 
72 puffing activity in relation to chromosomal inversions (De Frutos et al. 1984), the

73 genetic system of inversions present in American colonizing populations (Pegueroles et

74 al. 1996) and to reveal interpopulation differences in inversion polymorphism (Rasic et

75 al. 2008).

76 In the present study, our main aim is to assess whether the genetic architecture

77 for inversions of a well-adapted population, in its optimum climatic conditions, could

78 reach the expected homozygosity under a drastic inbreeding, or other evolutionary

79 forces (as selection to laboratory conditions) could modify the expectations. For this

80 purpose, we have chosen the Balkan population of Avala, a large and well established

81 population, and collected the D. subobscura sample during the expansion peak of the

82 species abundance. The inbreeding conditions have been a drastic 12 generations of

83 brother-sister mating. A second objective is to use the resulting inbred lines (obtained in

84 the previous inbreeding experiment) to study the adaptation of different chromosomal

85 combinations to two different temperature conditions $\left(13^{\circ} \mathrm{C}\right.$ and $\left.18^{\circ} \mathrm{C}\right)$.

86

87 Material and Methods

88 Population and samples

89 In this study, we analyzed a natural population of Drosophila subobscura

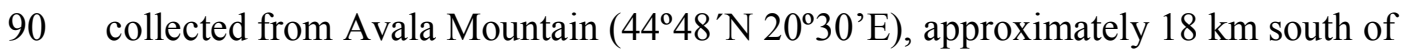

91 Belgrade, Serbia. A detailed description of this locality can be found in Zivanovic and

92 Mestres (2010a, b). D. subobscura individuals were sampled from a forest with

93 polydominant communities of Fagetum submontanum mixtum, which is about $450 \mathrm{~m}$

94 a.s.1. Flies were collected exactly at the same site of previous sampling (Zivanovic and

95 Mestres $2010 \mathrm{a}, \mathrm{b}$ ) from $30^{\text {th }}$ of May to $5^{\text {th }}$ of June 2011 . These days were chosen to

96 compare chromosomal polymorphism data with that from June 2004 (collected from the 
$972^{\text {nd }}$ to $9^{\text {th }}$ of June). The 2011 collection was sampled about 2 days at average earlier,

98 because spring/summer has advanced an average of 2.5 days per decade in Europe

99 (Menzel et al. 2006). Furthermore, D. subobscura presents the highest peak of

100 expansion during spring (Krimbas 1993; Argemí et al. 1999; Araúz et al. 2009).

101 Meteorological data for Avala Mountain (maximum, minimum and mean temperatures,

102 and rainfall) were recorded from Republic Hydrometeorological Service (Serbia). The

103 average values of these meteorological parameters during trapping days were:

104 maximum $\mathrm{T}=27.9 \mathrm{C}^{\mathrm{o}}$, minimum $\mathrm{T}=17.0 \mathrm{C}^{\mathrm{o}}$, mean $\mathrm{T}=22.6 \mathrm{C}^{\mathrm{o}}$ and rainfall $=0.98$

$105 \mathrm{~mm}$. Detailed weather information for all collecting days is shown in Table S1.

107 Inbreeding crosses and chromosomal preparation

108 We started the experiment with 28 isofemale lines from females sampled in

109 Avala Mountain. Each one was put in an individual vial with $25 \mathrm{ml}$ standard corn-meal-

110 sugar-agar-yeast medium, at $18^{\circ} \mathrm{C}, 60 \%$ relative humidity under a $12 \mathrm{~h} / 12 \mathrm{~h}$ light/dark

111 cycle. A detailed description of inbreeding procedure can be found in Pegueroles et al.

112 (1996). Couples (using virgin females) of offspring from the wild females were chosen

113 as parents of the first generation of sib mating. For each line and in every generation,

114 three or four (but in many cases even more) brother-sister pairs were mated in

115 individual vials. Among those that produce offspring, one of them was chosen to

116 continue the experiment. However, after 12 generations of a long systematic inbreeding

117 process, many consequences were evident: delay of development time, reduction in

118 viability and even many lines were lost. The number of surviving lines (in brackets) per

119 generation was the following: $\mathrm{G}_{4}(15), \mathrm{G}_{6}(11), \mathrm{G}_{8}(11), \mathrm{G}_{10}(8)$ and $\mathrm{G}_{12}(8)$.

120 For studying the effect of inbreeding on chromosomal inversion polymorphism,

121 third instar larvae were analyzed in the initial sample $\left(G_{0}\right)$ and also in $G_{4}, G_{6}, G_{8}, G_{10}$ 
122 and $\mathrm{G}_{12}$ generations. For the initial sample, only one son of each wild female was

123 crossed with virgin females of the Küsnacht strain, which is homokaryotypic for

124 standard chromosomal inversions in all five chromosomes. The polytene chromosomes

125 were stained and squashed in aceto-orcein solution. At least eight larvae from the

126 progeny of each cross were examined. For the cytological analysis of chromosomal

127 arrangements, the Kunze-Mühl and Müller (1958) chromosome map was used. The

128 designation of inversions and chromosomal arrangements followed that of Kunze-Mühl

129 and Sperlich (1955) and Krimbas (1993). The same procedure (only one male per line

130 was used) was repeated for the chromosomal studies in $\mathrm{G}_{4}, \mathrm{G}_{6}, \mathrm{G}_{8}, \mathrm{G}_{10}$ and $\mathrm{G}_{12}$

131 generations. Finally, the degree of chromosomal inversion polymorphism in the initial

132 and inbred lines was assessed using the index of free recombination (IFR) computed

133 according to Carson (1955).

135 Development time and fertility of inbred lines at different temperatures

136 After 12 generations of inbreeding process we selected the surviving lines (a

137 total of 8) to carry out a study of fertility. For each line, three replicates were founded

138 using 3 males and 3 virgin females and putting them in individual vials. These vials

139 were left, at the same time, in a chamber with an optimal temperature $\left(18^{\circ} \mathrm{C}\right)$. The

140 temperature was not changed, and after 7 days the parents were eliminated. Then, each

141 day at the same hour, the number of arising males and females was counted for each

142 vial. This procedure was repeated each day until the medium was exhausted. A similar

143 procedure was simultaneously carried out at rather cold temperature $\left(13^{\circ} \mathrm{C}\right)$, but in this

144 case the parents were eliminated after 10 days of crossings.

145

146 


\section{Mathematical and statistical methods}

148 The theoretical value of the inbreeding coefficient $F$ was calculated according to

149 Wright $(1921,1969)$, and it follows the nonhomogeneous second order difference

150 equation $F_{t}=\frac{1}{4}\left(1+2 F_{t-1}+F_{t-2}\right)$, where $F_{t}$ represents the inbreeding coefficient in the $t^{\text {th }}$

151 generation. In a given generation $t$, the expected karyotypic frequencies for the different

152 combinations of inversions (or arrangements) per chromosome were obtained using

153 inversion (or arrangements) frequencies ( $p, q, r, s$, etc.), considering each one as a single

154 allele, and using the corresponding $F$ value of the given generation (Wright 1931; Hartl

155 and Clark 1989; Hedrick 2000). Thus, for a homozygote the mathematic expression

156 would be: $P=p^{2}(1-F)+p F$, and for a heterozygote $H=2 p q(1-F)$.

157 For each chromosome, the differences between the observed and expected genotypic

158 frequencies in the $\mathrm{G}_{4}, \mathrm{G}_{8}$ and $\mathrm{G}_{12}$ generations of inbreeding were determined by two-

159 sided Fisher's exact test (statistically significant $p$-value $<0.05$ ). The same statistical

160 procedure was also carried out to compare the observed chromosomal frequencies

161 between $\mathrm{G}_{0}$ and $\mathrm{G}_{12}$. This test has been utilized because it is more accurate than chi-

162 squared test when the expected frequencies are small. Using the bootstrap procedure

163 (100000 runs) the corresponding $p$-values were obtained. These computations were

164 carried out with R package (http://CRAN.R-project.org).

165 To compare the beginning of fly emergence and the period of emergence (in

166 days) at the two development temperatures $\left(13^{\circ} \mathrm{C}\right.$ and $\left.18^{\circ}\right)$, a Mann-Whitney test was

167 computed. Also, to study fertility a factorial ANOVA, with fixed factors being

168 temperature, chromosomal line and replicates was computed. For a fixed $18{ }^{\circ} \mathrm{C}$ of

169 temperature, a factorial ANOVA with fixed factors being chromosomal line and

170 replicates was applied. When significances were detected, a pairwise Tukey analysis

171 was carried out. In the case of $13^{\circ} \mathrm{C}$, as very few individuals were born, a non- 
172 parametric one-way ANOVA (Kruskal-Wallis) was computed to ascertain the effect of

173 chromosomal line factor. All these analyses were carried out with R package

174 (http://CRAN.R-project.org).

175

176 Results

177 Variation of inversion polymorphism during inbreeding

178 The chromosomal polymorphism frequencies in the first generation $\left(\mathrm{G}_{0}\right)$ and in

179 the inbred after four $\left(G_{4}\right)$, six $\left(G_{6}\right)$, eight $\left(G_{8}\right)$, ten $\left(G_{10}\right)$ and twelve $\left(G_{12}\right)$ generations are

180 presented in Table 1. During the sib-mating process a reduction of viability in some

181 strains and a loss of lines were observed. In Fig. 1, variations in the inversions and

182 chromosomal arrangements frequencies during inbreeding generations are shown. For

183 most common inversions and arrangements, frequencies stabilization seems to begin in

$184 \mathrm{G}_{8}$ and confirm in $\mathrm{G}_{10}$. Likely, it is due to inbreeding coefficients values, which present

185 few changes from $\mathrm{G}_{8}(0.826)$ to $\mathrm{G}_{12}(0.926)$. In the chromosomal polymorphism

186 comparison between $\mathrm{G}_{0}$ and $\mathrm{G}_{12}$, there are no significant differences for any of the

187 chromosomes: A (Fisher's exact test, $p$-value $=0.8784), \mathrm{J}(p$-value $=1), \mathrm{U}(p$-value $=$

188 0.4059), $\mathrm{E}(p$-value $=0.8297)$ and $\mathrm{O}(p$-value $=0.2245)$.

189 With regard to karyotypic frequencies, the observed and expected (under

190 inbreeding model) values are presented in Table 2. For J chromosome there were not

191 significant differences in these frequencies for $\mathrm{G}_{4}(p$-value $=1), \mathrm{G}_{8}(p$-value $=1)$ and

$192 \mathrm{G}_{12}(p$-value $=1)$ generations. In the case of $\mathrm{U}$ chromosome, only $\mathrm{G}_{8}$ was significant: $\mathrm{G}_{4}$

$193(p$-value $=0.3104), \mathrm{G}_{8}(p$-value $=0.0240)$ and $\mathrm{G}_{12}(p$-value $=0.0534)$. Differences in $\mathrm{E}$

194 chromosome were not significant: $\mathrm{G}_{4}(p$-value $=0.7872), \mathrm{G}_{8}(p$-value $=1)$ and $\mathrm{G}_{12}(p$ -

195 value $=1)$. Finally, for the $\mathrm{O}$ chromosome, differences were neither significant: $\mathrm{G}_{4}(p-$

196 value $=0.9213), \mathrm{G}_{8}(p$-value $=0.9066)$ and $\mathrm{G}_{12}(p$-value $=1)$. During the inbreeding 
197 process an increment in IFR values can be observed (Table 2). This result is expected

198 because a consequence of inbreeding is an increase of homozygotes. Finally, it is worth

199 to study the chromosomal composition of the remaining inbred lines in $\mathrm{G}_{12}$ (Table 3 ). In

200 six of them (lines 1, 2, 5, 6, 7 and 8), one chromosome of the karyotype still segregated.

201 For the $\mathrm{O}$ chromosome, lines 1 and 2 presented the inversion or arrangements $\mathrm{O}_{\underline{3+4}+1}$;

$202 \mathrm{O}_{\underline{3+4}+\underline{22}}$ and $\mathrm{O}_{\mathrm{st}} ; \mathrm{O}_{\underline{3+4}+\underline{6}}$, respectively, whereas the other lines $(5,6,7$ and 8$)$ segregated

203 for the $\mathrm{U}$ chromosome, all with the combination $\mathrm{U}_{\underline{1}+\underline{2}} ; \mathrm{U}_{\underline{1+2+6}}$. For the $\mathrm{A}, \mathrm{J}$ and $\mathrm{E}$

204 chromosomes all lines were homokaryotypic. Thus, the percentages of fixation were

$205100 \%$ for the A, J and E chromosomes, but $75 \%$ and $50 \%$ for the $\mathrm{O}$ and $\mathrm{U}$

206 chromosomes, respectively. According to Schäfer (1937), after 12 generations of

207 brother-sister mating the expected percentage of fixation would be $85.9 \%$, if all initial

208 crosses were due to heterologous heterozygotes $\left(\mathrm{A}_{1} \mathrm{~A}_{2} \times \mathrm{A}_{3} \mathrm{~A}_{4}\right)$. This percentage could

209 be even larger if initially there were less different alleles (Haldane 1955).

210

211 Development time and fertility

212 The number of flies emerged at both temperatures are presented in Table S2

$213\left(13^{\circ} \mathrm{C}\right)$ and Table S3 $\left(18^{\circ} \mathrm{C}\right)$. For development time, the difference in the beginning of

214 fly emergence was significant between $13^{\circ} \mathrm{C}$ and $18^{\circ} \mathrm{C}$ (Mann-Whitney test, $\mathrm{W}=40.0$;

$215 p$-value $=0.004)$, whereas the period of emergence (in days) was no significant $(\mathrm{W}=$

$21620.0 ; p$-value $=0.941)$.

217 When comparing $13^{\circ} \mathrm{C}$ and $18^{\circ} \mathrm{C}$, significant differences in the number of flies

218 were obtained for temperature and chromosomal lines, but replicates were no significant

219 (Table 4). In all pairwise comparisons, differences between chromosomal lines were

220 due to line number 6 . When analyzing only $18^{\circ} \mathrm{C}$, the effect of chromosomal lines was

221 significant, but replicates factor was no significant (Table 5). As in the previous 
222 analysis, pairwise comparisons were significant for all cases where chromosomal line 6

223 was involved, with the exception of the comparison between lines 3 and 6 . For the $13^{\circ} \mathrm{C}$,

224 chromosomal lines factor was no significant (Kruskal-Wallis $=2.965 ; p$-value $=0.564)$.

225 Finally, a malformation resembling club mutation of D. melanogaster (Lindsley

226 and Zimm 1992) was observed in different lines, mainly those reared at $13^{\circ} \mathrm{C}$. It has

227 been observed that many Drosophila genus mutants tend to slightly increase their

228 viability at lower temperatures (Dobzhansky 1982; Lindsley and Zimm 1992;

229 Ashburner et al. 2005). However, flies which emerged with their wings drastically

230 reduced died soon.

231

\section{Discussion}

233 In the $\mathrm{G}_{0}$, the inversions (or chromosomal arrangements) and karyotypes found

234 are characteristic of Avala mountain population (Zivanovic and Mestres 2010a) and also

235 of the Balkan region (Zivanovic et al. 1995, 2002; Zivanovic 2007; Rasic et al. 2008;

236 Stamenkovic-Radak et al. 2008; Kenig et al. 2010; Zivanovic and Mestres 2011; Jelic et

237 al. 2012). No significant changes between $G_{0}$ and $G_{12}$ were observed for the inversion

238 and arrangement frequencies. In inbreeding experiments using D. subobscura, other

239 authors (although analyzing fewer inbreeding generations) found similar results

240 (Pegueroles et al. 1996; Rasic et al. 2008). Furthermore, most inversions (or

241 arrangements) seem to reach stabilization around $\mathrm{G}_{8}$ (Fig. 1). In general, no significant

242 differences were neither detected when comparing the observed and expected (under

243 inbreeding model) karyotypes. For all these reasons, it seems that inbreeding is the

244 leading factor acting on inversions (or arrangements) and karyotypes, whereas the

245 effects other evolutionary forces appear to be secondary. Also, values of IFR along

246 generations changed accordingly with the increasing levels of inbreeding. 
However, there were many exceptions: for instance, significant differences for

the $\mathrm{U}$ chromosome were found in $\mathrm{G}_{8}$. Likely, these are due to an increase of $\mathrm{U}_{\underline{1}+\underline{2}} / \mathrm{U}_{\underline{1+2+6}}$

249 and a decrease of $\mathrm{U}_{\underline{1+2+6}} / \mathrm{U}_{\underline{1+2+6}}$ karyotypes (Table 2). It is worth to point out that $\mathrm{U}_{\underline{1}+\underline{2}}$;

$250 \mathrm{U}_{\underline{1+2+6}}$ arrangements were found still segregating in four lines at the end of the

251 inbreeding experiment $\left(\mathrm{G}_{12}\right)$ (Table 3$)$. In this last generation, this was not the only case

252 of segregating arrangemets: two lines had no fixation for the $\mathrm{O}$ chromosome, presenting

253 the $\mathrm{O}_{\underline{3+4+1}} ; \mathrm{O}_{\underline{3+4}+22}$ and $\mathrm{O}_{\text {st }} ; \mathrm{O}_{\underline{3+4+6}+\underline{6}}$ constitution (Table 3). Thus, considering all lines

254 together, six out eight lines presented segregation for at least one chromosome. $U_{\underline{1}}+\underline{2}$

255 seems to be an ancient arrangement (Krimbas 1993) and "warm" adapted (Menozzi and

256 Krimbas 1999; Solé et al. 2002) and it was fixed in four of the final inbred lines and still

257 segregated with $U_{\underline{1+2+6}}$ in the remaining four. This latter arrangement presents a typical

258 Balkan distribution, and in this region it could confer an adaptive advantage to its

259 carriers. The inbreeding experiment was carried out at constant $18^{\circ} \mathrm{C}$, and in general, it

260 is considered a good temperature for the species (Buzzati-Traverso 1942; Rocha-Pité

261 1980; Krimbas 1993; Santos et al. 2004, 2005). With regard to O chromosome, the

262 segregating arrangements $\mathrm{O}_{\underline{3+4}+1} ; \mathrm{O}_{\underline{3+4+22}}$ (Line 1) was a surprising combination (Table

263 3), because they are not the most frequent $\mathrm{O}$ chromosome arrangements in Avala

264 population (Table 1). The first arrangement presents rather high frequencies in Balkan

265 populations (Krimbas 1993), depending on the population and date of the sample

266 (ranging from 5.0 to 27.0\%) (Zivanovic et al. 1995, 2002; Zivanovic 2007; Zivanovic

267 and Mestres 2010a, 2011; Zivanovic et al. 2012). The second one $\left(\mathrm{O}_{\underline{3+4}+\underline{22}}\right)$ is also

268 common in the Balkans (Krimbas 1993), and can be found in frequencies ranging from

2696.5 to $16.7 \%$ (Zivanovic et al. 2002; Zivanovic 2007; Zivanovic and Mestres 2010a,

270 2011; Zivanovic et al. 2012). Maybe despite the inbreeding, they were segregating due

271 to lethal genes trapped inside the $\mathrm{O}_{1}$ and $\mathrm{O}_{22}$ inversions, because they are small and 
272 recombination inside them is dramatically reduced (Albornoz and Dominguez 1994;

273 Chang and Lin 1995; Chang et al. 1996; Yang et al. 2002; Mestres et al. 2009).

274 However, this possibility is only speculative. The $\mathrm{O}$ arrangements segregating in Line 2,

$275 \mathrm{O}_{\text {st }}$ and $\mathrm{O}_{\underline{3+4+}+\underline{6}}$, (Table 3) is also surprising, because the latter is infrequent in the

276 Balkans (Krimbas 1993), where it has been seldom detected and presenting very low

277 frequencies (Zivanovic et al. 2002; Zivanovic and Mestres 2010a; Zivanovic et al.

278 2012). However, under laboratory conditions $\mathrm{O}_{\underline{3+4}+\underline{6}}$ had a higher segregation than

279 expected in the heterokaryotypes (Pegueroles et al. 2010).

280 If we focus in the inversions (or arrangements) fixed, there was variability for

281 the A chromosome, because $\mathrm{A}_{1}, \mathrm{~A}_{2}$ and $\mathrm{A}_{\mathrm{st}}$ were in homozygous condition in three, one

282 and four lines, respectively (Table 3). It is an expected result due to the initial

283 composition of the sample (Table 1). For the J chromosome, two and six lines were

284 fixed for the $\mathrm{J}_{\mathrm{st}}$ and $\mathrm{J}_{1}$ inversions, respectively. This result is also compatible with the

285 initial sample composition (Table 1). However, U chromosome presented interesting

286 results, because four lines had the $\mathrm{U}_{\underline{1}+\underline{2}}$ arrangement fixed, whereas in the remaining

287 lines the $\mathrm{U}_{\underline{1}+\underline{2}} ; \mathrm{U}_{\underline{1+2+6}}$ combination was segregating. This situation has been previously

288 commented, but it is worth noting that no inbred line showed the $\mathrm{U}_{\underline{1+2+6}}$ arrangement

289 fixed at the end of the process. This arrangement is not lethal per se, because

290 homozygotes for it were recorded in the initial sample of flies. With regard to the $\mathrm{E}$

291 chromosome, all inbred lines reached a fixation status: $E_{s t}, E_{8}$ and $E_{\underline{1+2+9}}$ were fixed in

292 three, two and three lines, respectively. This result could be considered as expected,

293 because they presented the highest frequencies at the beginning of the inbreeding

294 process. However, $\mathrm{E}_{\mathrm{st}} / \mathrm{E}_{\mathrm{st}}$ was recorded at a higher frequency than expected (Table 2),

295 although it is considered a "cold" adapted inversion and the inbreeding experiment was

296 developed at constant $18^{\circ} \mathrm{C}$. This is not the case for the other two arrangements: for the 
$297 \mathrm{E}_{\underline{1+2+9}} / \mathrm{E}_{\underline{1+2+9}}$ the opposite tendency was detected and for the $\mathrm{E}_{8} / \mathrm{E}_{8}$ karyotypes, observed

298 and expected values were very similar. Finally the O chromosome, as previously

299 commented, presented two inbred lines where arrangements are still segregating, but six

300 were fixed for the same arrangements: $\mathrm{O}_{\text {st }}$ (two lines), $\mathrm{O}_{\underline{3+4}}$ (three lines) and $\mathrm{O}_{\underline{3+4}+\underline{7}}$

301 (only one line). Although $\mathrm{O}_{\text {st }}$ is considered a "cold" adapted arrangement and

302 inbreeding conditions seem a priori not favor it, its frequency was increasing along the

303 inbreeding experiment (Table 1) until reaching a plateau (Fig. 1). The result observed

304 for the $\mathrm{O}_{\underline{3+4}}$ could be considered as expected, but its frequency had a tendency to

305 decrease. However, the inbred line with the fixed arrangement $\mathrm{O}_{\underline{3+4}+\underline{7}}$ was really

306 surprising. This arrangement is very uncommon in the Balkan region (Krimbas 1993;

307 Zivanovic et al. 1995, 2002; Zivanovic 2007; Zivanovic and Mestres 2010a, 2011;

308 Zivanovic et al. 2012), but it is frequent in the Western Mediterranean (Prevosti et al.

309 1984; Krimbas 1993; Orengo and Prevosti 1996; Solé et al. 2002; Araúz et al. 2009) and

310 American colonizing populations (Prevosti et al. 1988, 1990; Balanyà et al. 2003;

311 Mestres et al. 2009; Castañeda et al. 2013). It was also described in Asia Minor and

312 Israel, but data available from these regions are not recent (Goldschmidt 1956; Götz

313 1967; Malogolowkin-Cohen and Sperlich 1981). In the present study, its initial

314 frequency was so small that it was undetected in $\mathrm{G}_{0}$ (Table 1). In $\mathrm{G}_{4}, \mathrm{O}_{\underline{3+4+}+\underline{7}} / \mathrm{O}_{\underline{3+4}+\underline{7}}$

315 homozygotes were detected for the first time and their frequency was increasing until

$316 \mathrm{G}_{12}$ (Table 2). It could be interpreted that this combination was adaptive for the

317 particular laboratory rearing conditions. Furthermore, this adaptation to laboratory

318 conditions seems to be supported by an experiment of Pegueroles et al. (2010): in

$319 \mathrm{O}_{\underline{3+4}} / \mathrm{O}_{\underline{3+4}+\underline{7}}$ individuals, a significant deviation of random segregation was observed,

320 being the $\mathrm{O}_{\underline{3+4}+\underline{7}}$ gametes in higher proportion than expected. 
321 Although the inbreeding process until $\mathrm{G}_{12}$ was very drastic for D. subobscura

322 individuals, valuable information on development time and fertility was gathered using

323 the inbred lines. It is well know that species of Drosophila genus develop faster at

324 higher temperatures (for a review see Kuntz and Eisen 2014) and D. subobscura is not

325 an exception (Krimbas 1993). It seems that developing time is adaptive to climate, but

326 the relative timing of main events in Drosophila embryogenesis seem to be constant

327 (Kuntz and Eisen 2014). In the present research, we have found significant differences

328 in the beginning time of fly emergence, but not in the period of emergence. When

329 comparing the inbred lines reared at $13^{\circ} \mathrm{C}$ and $18^{\circ} \mathrm{C}$, significant differences were

330 observed in the number of flies obtained. According to this result, Santos (2007) found

331 also lower fitness at $13^{\circ} \mathrm{C}$ than at $22^{\circ} \mathrm{C}$. With regard to the number of flies, we also

332 found significant differences between chromosomal lines. This effect is mainly due to

333 inbred line number 6 , in which the infrequent arrangement in the Balkans $\mathrm{O}_{\underline{3+4+}+\underline{7}}$ was

334 fixed. However, as previously commented, this arrangement could be adaptive to

335 laboratory rearing conditions. Analyzing the whole karyotype of this inbred line and

336 using the classification of inversions and arrangements in "cold" and "warm" according

337 to Rego et al. (2010), based on Menozzi and Krimbas (1992), then inbred line 6 is: $A_{1}$

338 (cold), $\mathrm{J}_{1}$ (warm), $\mathrm{U}_{\underline{1}+\underline{2}}\left(\right.$ warm); $\mathrm{U}_{\underline{1+2+6}}, \mathrm{E}_{8}$ and $\mathrm{O}_{\underline{3+4}+\underline{7}}$. Thus, not a clear pattern of

339 'thermal adaptation' is observed in this inbred line.

340 In summary, we hypothesize that the main evolutionary force in the present

341 research was inbreeding, but during the experimental process flies seem also to adapt in

342 some way to laboratory conditions. Inversions seem to adapt not only to temperature,

343 but to other environmental factors. Thus, results obtained in laboratory experiments

344 reflect the adaptive potential of $D$. subobscura inversions, even after a severe

345 disturbance produced by inbreeding. 


\section{Acknowledgements}

This study was supported by grant number 173025 from the Ministry of

348 Education, Science and Technological Development of the Republic of Serbia, grant

349 CTM2013-48163-C2-2-R from the Ministerio de Economía y Competitividad (Spain)

350 and grants 2014 SGR 336 and 2014 SGR 464 from the Generalitat de Catalunya

351 (Spain). FM is member of the IRBio (Institut de Recerca de la Biodiversitat, Universitat

352 de Barcelona).

353

354 References

355 Albornoz, J., and Dominguez, A. 1994. Inversion polymorphism and accumulation of

356 lethals in selected lines of Drosophila melanogaster. Heredity 73: 92-97.

357

358 Argemí, M., Monclús, M., Mestres, F., and Serra, L. 1999. Comparative analysis of a

359 community of Drosophilids (Drosophilidae; Diptera) sampled in two periods widely

360 separated in time. J. Zool. Syst. Evol. Res. 37: 203-210.

361

362 Araúz, P.A., Mestres, F., Pegueroles, C., Arenas, C., Tzannidakis, G., Krimbas, C.B., et

363 al. 2009. Tracking the origin of the American colonization by Drosophila subobscura:

364 genetic comparison between Eastern and Western Mediterranean populations. J. Zool.

365 Syst. Evol. Res. 47: 25-34.

366

367 Ashburner, M., Golic, K.G., and Hawley, R.S. 2005. Drosophila. A laboratory

368 handbook. $2^{\text {nd }}$ ed. Cold Spring Harbor Lab. Press. N.Y.

369 
370 Balanyà, J., Serra, L., Gilchrist, G.W., Huey, R.B., Pascual, M., Mestres, F., et al. 2003.

371 Evolutionary pace of chromosomal polymorphism in colonizing populations of

372 Drosophila subobscura: an evolutionary time series. Evolution 57: 1837-1845.

373

374 Balanyà, J., Solé, E., Oller, J.M., Sperlich, D., and Serra, L. 2004. Long-term changes in

375 the chromosomal inversion polymorphism of Drosophila subobscura. II. European

376 populations. J. Zool. Syst. Evol. Res. 42: 191-201.

377

378 Balanyà, J., Oller, J.M., Huey, R.B., Gilchrist, G.W., and Serra, L. 2006. Global genetic

379 change tracks global climate warming in Drosophila subobscura. Science 313:

$380 \quad 1773-1775$.

381

382 Balanyà, J., Huey, R.B., Gilchrist, G.W., and Serra, L. 2009. The chromosomal

383 polymorphism of Drosophila subobscura: a micro evolutionary weapon to monitor

384 global change. Heredity 103: 364-367.

385

386 Buzzati-Traverso, A.A. 1942. Genetica di popolazioni in Drosophila. I. Eterozigosi in

387 Drosophila subobscura Collin. Scientia Genet. 2: 190-223.

388

389 Carson, H.L. 1955. The genetic characteristics of marginal populations of Drosophila.

390 Cold Spring Harbor Symp. Quant. Biol. 20: 276-287.

391

392 Castañeda, L.E., Balanyà, J., Rezende, E.L., and Santos, M. 2013. Vanishing

393 chromosomal inversion clines in Drosophila subobscura from Chile: Is behavioral

394 thermoregulation to blame? Am. Nat. 182: 249-259. 
396 Chang, H., and Lin, F.-J. 1995. The interaction between chromosomal inversion and

397 recessive lethals in Drosophila albomicans. Zool. Stud. 34: 47-54.

398

399 Chang, H., Lan, S.-F., and Lin, F.-J. 1996. Population significance of high frequency

400 recessive lethals in Drosophila albomicans. Zool. Stud. 35: 138-145.

401

402 De Frutos, R., Latorre, A., and Pascual, L. 1984. Patterns of puffing activity and

403 chromosomal polymorphism in Drosophila subobscura. 3. Puffing activity depression

404 by inbreeding. Theor. Appl. Genet. 69: 101-110.

405

406

Dobzhansky, Th. 1982. Genetics and the origin of species. Columbia University Press.

407 N.Y.

408

409 Fontdevila, A., Zapata, C., Alvarez, G., Sanchez, L., Méndez, J., and Enriquez, I. 1983.

410 Genetic coadaptation in the chromosomal polymorphism of Drosophila subobscura. I.

411 Seasonal changes of gametic disequilibrium in a natural population. Genetics 105: 935412955.

413

414 Goldschmidt, E. 1956. Chromosomal polymorphism in a population of Drosophila 415 subobscura from Israel. J. Genet. 54: 474-496.

416

417 Götz,W. 1967. Untersuchungen über den chromosomalen Strukturpolymorphismus in 418 kleinasiatischen und persischen Populationen von Drosophila subobscura Coll. Mol.

419 Gen. Genet. 100: 1-38. 
421 Haldane, J.B.S. 1955. The complete matrices for brother-sister and alternate parent-

422 offspring mating involving one locus. J. Genet. 53: 315-324.

423

424 Hartl, D.L., and Clark, A.G. 1989. Principles of population genetics. $2^{\text {nd }}$ ed., Sinauer 425 Associates, Inc. Pub., Sunderland (MA).

426

427 Hedrick, P.W. 2000. Genetics of populations. $2^{\text {nd }}$ ed., Jones and Bartlett Pub., Sudbury 428 (MA).

429

430 Hollingsworth, M.J., and Maynard Smith, J. 1955. The effects of inbreeding on rate of 431 development and on fertility in Drosophila subobscura. J. of Genet. 53: 295-314.

433 Jelic, M., Castro, J.A., Kurbalija-Novicic, Z., Kenig, B., Dimitrijevic, D., Savic-

434 Veselinovic, M. et al. 2012. Absence of linkage disequilibria between chromosomal

435 arrangements and mtDNA haplotypes in natural populations of Drosophila subobscura 436 from the Balkan Peninsula. Genome 55: 214-221.

437

438 Kenig, B., Jelic, M., Kurbalija, Z., Stamenkovic-Radak, M., and Andjelkovic, M. 2010.

439 Inversion polymorphism in populations of Drosophila subobscura from urban and non-

440 urban environments. Arch. Biol. Sci. Belgrade 62: 565-574.

441

442 Krimbas, C.B. 1992. The inversion polymorphism of Drosophila subobscura. In 443 Drosophila inversion polymorphism. Edited by C.B. Krimbas and J.R. Powell. CRC

444 Press, Inc. Boca Raton (FL). pp. 127-220. 
446 Krimbas, C.B. 1993. Drosophila subobscura: Biology, Genetics and Inversion

447 polymorphism. Verlag Dr. Kovac, Hamburg.

448

449 Krimbas, C.B., and Loukas, M. 1980. The inversion polymorphism of Drosophila

$450 \quad$ subobscura. Evol. Biol. 12: 163-234.

451

452 Kuntz, S.G., and Eisen, M.B. 2014. Drosophila embryogenesis scales uniformly across

453 temperature in developmentally diverse species. PloS Genetics 10: e1004293.

454

455 Kunze-Mühl, E., und Müller, E. 1958. Weitere Untersuchungen uber die chromosomale

456 Struktur und die naturlichen Strukturtypen von Drosophila subobscura. Chromosoma 9:

$457 \quad 559-570$.

458

459 Kunze-Mühl, E., und Sperlich, D. 1955. Inversionen und chromosomale Strukturtypen

460 bei Drosophila subobscura. Z. Indukt. Abstamm.- u. Vererb.-Lehre 87: 65-84.

461

462 Latorre, A., Hernández, C., Martínez, D., Castro, J.A., Ramón, M., and Moya, A. 1992.

463 Population structure and mitochondrial DNA gene flow in Old World populations of

464 Drosophila subobscura. Heredity 68: 15-24.

465

466 Lindsley, D.L., and Zimm, G.G. 1992. The genome of Drosophila melanogaster.

467 Academic Press, San Diego (CA).

468 
469 Malogolowkin-Cohen, Ch., and Sperlich, D. 1981. The effect of isolation and

470 marginality on the inversion polymorphism of Drosophila subobscura in Israel. Rev.

471 Bras. Genet. 2: 213-230.

472

473 Menozzi, P., and Krimbas, C.B. 1992. The inversion polymorphism of Drosophila

474 subobscura revisited: synthetic maps of gene arrangement frequencies and their

475 interpretation. J. Evol. Biol. 5: 625-641.

476

477 Menzel, A., Sparks, T.H., Estrella, N., Koch, E., Aasa, A., Ahas, R., et al. 2006.

478 European phenological response to climate change matches the warming pattern. Global

479 Change Biol. 12: 1969-1976.

480

481 Mestres, F., Balanyà, J., Arenas, C., Solé, E., and Serra, L. 2001. Colonization of

482 America by Drosophila subobscura: heterotic effect of chromosomal arrangements

483 revealed by the persistence of lethal genes. Proc. Natl. Acad. Sci. USA 98: 9167-9170.

484

485 Mestres, F., Balanyà, J., Pascual, M., Arenas, C., Gilchrist, G.W., Huey, R.B., et al.

486 2009. Evolution of Chilean colonizing populations of Drosophila subobscura: lethal

487 genes and chromosomal arrangements. Genetica 136: 37-48.

488

489 Orengo, D.J., and Prevosti, A. 1996. Temporal changes in chromosomal polymorphism

490 of Drosophila subobscura related to climatic changes. Evolution 50: 1346-1350.

491 
492 Pascual, M., Aquadro, C.F., Soto, V., and Serra, L. 2001. Microsatellite variation in

493 colonizing and Palearctic populations of Drosophila subobscura. Mol. Biol. Evol. 18:

$494 \quad 731-740$.

495

496 Pegueroles, C., Ordoñez, V., Mestres, F., and Pascual, M. 2010. Recombination and

497 selection in the maintenance of the adaptive value of inversions. J. Evol. Biol. 23:

$498 \quad 2709-2717$.

499

500 Pegueroles, C., Aquadro, C.F., Mestres, F., and Pascual, M. 2013. Gene flow and gene

501 flux shape evolutionary patterns of variation in Drosophila subobscura. Heredity 110: $502502-529$.

503

504 Pegueroles, G., Mestres, F., and Serra L. 1996. Analysis of inbreeding in a colonizing 505 population of Drosophila subobscura. Genetica 98: 289-296.

506

507 Powell, J.R. 1997. Progress and Prospects in Evolutionary Biology: The Drosophila 508 Model. Oxford University Press, Oxford, UK.

509

510 Prevosti, A., Frutos, R. de, Alonso, G., Latorre, A., Monclus, M., Martinez, M.J. 1984.

511 Genetic differentiation between natural populations of Drosophila subobscura in the

512 Western Mediterranean area with respect to chromosomal variation. Génét. Sél. Evol.

513 16: $143-156$.

514

515 Prevosti, A., Ribo, G., Serra, L., Aguade, M., Balaña, J., Monclus, M., et al. 1988.

516 Colonization of America by Drosophila subobscura: Experiment in natural populations 
517 that supports the adaptive role of chromosomal-inversion polymorphism. Proc. Natl.

518 Acad. Sci. USA 85: 5597-5600.

519

520 Prevosti, A., Serra, L., Segarra, C., Aguade, M., Ribo, G., and Monclus, M. 1990.

521 Clines of chromosomal arrangements of Drosophila subobscura in South America

522 evolve closer to Old World patterns. Evolution 44: 218-221.

523

524 Rasic, G., Stamenkovic-Radak, M., Savic, T., and Andjelkovic, M. 2008. Inbreeding

525 reveals interpopulation differences in inversion polymorphism of Drosophila

526 subobscura. J. Zool. Syst. Evol. Res. 46: 31-37.

527

528 Rego, C., Balanyà, J., Fragata, I., Matos, M., Rezende, E.L., and Santos, M. 2010.

529 Clinal patterns of chromosomal inversion polymorphism in Drosophila subobscura are

530 partly associated with thermal preferences and heat stress resistance. Evolution 64: $385-$ 531397.

532

533 Rocha-Pité, M.T. 1980. Stratégies adaptatives et Biologie des populations de

534 Drosophilides de quelques habitats typiques de Portugal. Thèse de Doctorat d'Etat.

535 Université de Paris VI. France.

536

537 Rodríguez-Trelles, F., and Rodríguez, M.A. 1998. Rapid micro-evolution and loss of 538 chromosomal diversity in Drosophila in response to climate warming. Evol. Ecol. 12: $539829-838$.

540 
541 Rodríguez-Trelles, F., Alvarez, G., and Zapata, C. 1996. Time-series analysis of

542 seasonal changes of the O inversion polymorphism of Drosophila subobscura. Genetics

543 142: 179-187.

544

545 Santos, M. 2007. Evolution of total net fitness in thermal lines: Drosophila

546 subobscura likes it 'warm'. J. Evol. Biol. 20: 2361-2370.

547

548 Santos, M., Fernández-Iriarte, P., Céspedes, W., Balanyà, J., Fontdevila, A., and Serra,

549 L. 2004. Swift laboratory thermal evolution of wing shape (but not size) in Drosophila

550 subobscura and its relationship with chromosomal inversion polymorphism. J. Evol.

551 Biol. 17: 841-855.

552

553 Santos, M., Céspedes, W., Balanyà, J., Trotta, V., Calboli, F.C.F., Fontdevila, A., et al.

554 2005. Temperature-related genetic changes in laboratory populations of Drosophila

555 subobscura: evidence against simple climatic-based explanations for latitudinal clines.

556 Am. Nat. 165: 258-273.

557

558 Schäfer, W. 1937 Über die Zunahme der Isozygotie (Gleicherbigkeit) bei fortgesetzter

559 Bruder-Schwester-Inzucht. Z. Indukt. Abstamm.-u. Vererbungslehre 72: 50-79.

560

561 Solé, E., Balanyà, J., Sperlich, D., and Serra, L. 2002. Long-term changes in the

562 chromosomal inversion polymorphism of Drosophila subobscura. I. Mediterranean

563 populations from southwestern Europe. Evolution 56: 830-835.

564 
565 Sperlich, D., and Pfriem, P. 1986. Chromosomal polymorphism in natural and

566 experimental populations. In The Genetics and Biology of Drosophila. Edited by M.

567 Ashburner, H.L. Carson and J.N. Thompson Jr. Vol. 3e. Academic Press, London, UK, 568 pp. 257-309.

569

570 Stamenkovic-Radak, M., Rasic, G., Savic, T., Kalajdzic, P., Kurbalija, Z., Kenig, B., et

571 al. 2008. Monitoring of the genetic structure of natural populations: change of the

572 effective population size and inversion polymorphism in Drosophila subobscura.

573 Genetica 133: 57-63.

574

575 Wright, S. 1921. Systems of mating. II. The effects of inbreeding on the genetic

576 composition of a population. Genetics 6: 124-143.

577

578 Wright, S. 1931. Evolution in Mendelian populations. Genetics 16: 97-159.

579

580 Wright, S. 1969. Evolution and the Genetics of populations. Vol. 2. The theory of gene

581 frequencies. The University of Chicago Press, Chicago (IL).

582

583 Yang, Y.-Y., Lin, F.-J., and Chang, H.-Y. 2002. Comparison of recessive lethal

584 accumulation in inversion-bearing and inversion-free chromosomes in Drosophila.

585 Zool. Stud. 41: 271-282.

586

587 Zivanovic, G. 2007. Seasonal changes in chromosomal inversion polymorphism in a

588 Drosophila subobscura natural population from a Southeastern European continental

589 refugium of the last glaciation period. Russ. J. Genet. 43: 1344-1349. 
591 Zivanovic, G., and Mestres, F. 2010a. Viabilities of Drosophila subobscura homo- and

592 heterokaryotypes at optimal and stress temperatures. I. Analysis over several years.

593 Hereditas 147: 70-81.

594

595 Zivanovic, G., and Mestres, F. 2010b. Viabilities of Drosophila subobscura homo- and 596 heterokaryotypes at optimal and stress temperatures. II. Seasonal component analysis. 597 Hereditas 147: 82-89.

598

599 Zivanovic, G., and Mestres, F. 2011. Changes in chromosomal polymorphism and 600 global warming: the case of Drosophila subobscura from Apatin (Serbia). Genet. Mol.

601 Biol. 34: 489-495.

602

603

604 Zivanovic, G., Andjelkovic, M., and Marinkovic, D. 2002. Chromosomal inversion 605 polymorphism of Drosophila subobscura from south-eastern part of Europe. J. Zool.

606 Syst. Evol. Res. 40: 201-204.

607

608 Zivanovic, G., Arenas, C., and Mestres, F. 2007. The genetic structure of Balkan

609 populations of Drosophila subobscura. Hereditas 144: 120-128.

610

611 Zivanovic, G., Arenas, C., and Mestres, F. 2012. Short- and long-term changes in

612 chromosomal inversion polymorphism and global warming: Drosophila subobscura

613 from the Balkans. Isr. J. Ecol. Evol. 58: 289-311.

614 
615 Zivanovic, G., Milanovic, M., and Andjelkovic, M. 1995. Chromosomal inversion

616 polymorphism of Drosophila subobscura populations from Jastrebac Mountain shows

617 temporal and habitat-related changes. J. Zool. Syst. Evol. Res. 33: 81-83.

618

619

620 FIGURE LEGENDS

621 Fig 1. Variations of inversions and chromosomal arrangements frequencies (in 622 percentage) during the inbreeding experiment (from $\mathrm{G}_{0}$ to $\mathrm{G}_{12}$ ). (A) Chromosome $A$,

623 (B) Chromosome J, (C) Chromosome U, (D) Chromosome E and (E) Chromosome O. 
Table 1. Frequencies of D. subobscura chromosomal inversions and arrangements from the initial generation $\left(\mathrm{G}_{0}\right)$ and in the inbreed lines after four $\left(\mathrm{G}_{4}\right)$, six $\left(\mathrm{G}_{6}\right)$, eight $\left(\mathrm{G}_{8}\right)$, ten $\left(\mathrm{G}_{10}\right)$ and twelve $\left(\mathrm{G}_{12}\right)$ generations. We have used the nomenclature of Kunze-Mühl and Sperlich (1955) and Krimbas (1993).

Inbreeding generation

\begin{tabular}{llllll}
\hline $\mathrm{G}_{0}$ & $\mathrm{G}_{4}$ & $\mathrm{G}_{6}$ & $\mathrm{G}_{8}$ & $\mathrm{G}_{10}$ & $\mathrm{G}_{12}$
\end{tabular}

\begin{tabular}{lllllllllllll}
\cline { 2 - 6 } Chrom. arrangements & $\mathrm{n}$ & $\%$ & $\mathrm{n}$ & $\%$ & $\mathrm{n}$ & $\%$ & $\mathrm{n}$ & $\%$ & $\mathrm{n}$ & $\%$ & $\mathrm{n}$ & $\%$
\end{tabular}

\begin{tabular}{|c|c|c|c|c|c|c|c|c|c|c|c|c|}
\hline $\mathrm{A}_{\mathrm{st}}$ & 13 & 46.4 & 5 & 33.3 & 5 & 45.5 & 6 & 54.5 & 4 & 50.0 & 4 & 50.0 \\
\hline $\mathrm{A}_{1}$ & 8 & 28.6 & 5 & 33.3 & 5 & 45.5 & 4 & 36.4 & 3 & 37.5 & 3 & 37.5 \\
\hline $\mathrm{A}_{2}$ & 7 & 25.0 & 5 & 33.3 & 1 & 9.0 & 1 & 9.1 & 1 & 12.5 & 1 & 12.5 \\
\hline Total & 28 & & 15 & & 11 & & 11 & & 8 & & 8 & \\
\hline $\mathrm{J}_{\mathrm{st}}$ & 15 & 26.8 & 9 & 30.0 & 7 & 31.8 & 7 & 31.8 & 4 & 25.0 & 4 & 25.0 \\
\hline $\mathrm{J}_{1}$ & 41 & 73.2 & 21 & 70.0 & 15 & 68.2 & 15 & 68.2 & 12 & 75.0 & 12 & 75.0 \\
\hline Total & 56 & & 30 & & 22 & & 22 & & 16 & & 16 & \\
\hline $\mathrm{U}_{\mathrm{st}}$ & 6 & 10.7 & 1 & I & 1 & 1 & I & I & 1 & 1 & 1 & 1 \\
\hline $\mathrm{U}_{\underline{1}+\underline{2}}$ & 33 & 58.9 & 18 & 60.0 & 15 & 68.2 & 17 & 77.3 & 12 & 75.0 & 12 & 75.0 \\
\hline $\mathrm{U}_{\underline{1+2+6}}$ & 12 & 21.4 & 10 & 33.3 & 7 & 31.8 & 5 & 22.7 & 4 & 25.0 & 4 & 25.0 \\
\hline $\mathrm{U}_{\underline{1+8}+\underline{2}}$ & 5 & 8.9 & 2 & 6.7 & I & I & I & I & I & I & I & I \\
\hline Total & 56 & & 30 & & 22 & & 22 & & 16 & & 16 & \\
\hline $\mathrm{E}_{\mathrm{st}}$ & 15 & 26.8 & 7 & 23.3 & 7 & 31.8 & 5 & 22.7 & 6 & 37.5 & 6 & 37.5 \\
\hline $\mathrm{E}_{\underline{1+2}}$ & 1 & 1.8 & I & I & I & I & I & I & I & I & I & I \\
\hline $\mathrm{E}_{\underline{1+2+9}}$ & 25 & 44.6 & 15 & 50.0 & 6 & 27.3 & 9 & 40.9 & 6 & 37.5 & 6 & 37.5 \\
\hline
\end{tabular}




\begin{tabular}{|c|c|c|c|c|c|c|c|c|c|c|c|c|}
\hline $\mathrm{E}_{\underline{1+2+9+12}}$ & 1 & 1.8 & 1 & 3.3 & I & / & I & I & I & I & I & I \\
\hline $\mathrm{E}_{8}$ & 14 & 25.0 & 7 & 23.3 & 9 & 40.9 & 8 & 36.4 & 4 & 25.0 & 4 & 25.0 \\
\hline Total & 56 & & 30 & & 22 & & 22 & & 16 & & 16 & \\
\hline $\mathrm{O}_{\mathrm{st}}$ & 12 & 21.4 & 7 & 23.3 & 6 & 27.3 & 7 & 31.8 & 5 & 31.2 & 5 & 31.2 \\
\hline $\mathrm{O}_{\underline{3+4}}$ & 26 & 46.4 & 11 & 36.7 & 7 & 31.8 & 8 & 36.4 & 6 & 37.5 & 6 & 37.5 \\
\hline $\mathrm{O}_{\underline{3+4}+1}$ & 8 & 14.3 & 4 & 13.3 & 2 & 9.1 & 1 & 4.5 & 1 & 6.3 & 1 & 6.3 \\
\hline $\mathrm{O}_{\underline{3+4}+\underline{5}}$ & 1 & 1.8 & I & I & I & I & I & I & I & I & I & I \\
\hline $\mathrm{O}_{\underline{3+4}+\underline{6}}$ & 1 & 1.8 & 2 & 6.7 & 1 & 4.5 & I & I & 1 & 6.3 & 1 & 6.3 \\
\hline $\mathrm{O}_{\underline{3+4}+\underline{7}}$ & I & I & 2 & 6.7 & 2 & 9.1 & 2 & 9.1 & 2 & 12.5 & 2 & 12.5 \\
\hline $\mathrm{O}_{\underline{3+4+8}}$ & 2 & 3.6 & 1 & 3.3 & 2 & 9.1 & 1 & 4.5 & I & I & I & I \\
\hline $\mathrm{O}_{\underline{3+4}+\underline{22}}$ & 6 & 10.7 & 3 & 10.0 & 2 & 9.1 & 3 & 13.6 & 1 & 6.3 & 1 & 6.3 \\
\hline Total & 56 & & 30 & & 22 & & 22 & & 16 & & 16 & \\
\hline
\end{tabular}


Table 2. Observed and expected frequencies of chromosomal karyotypes in the first generation $\left(G_{0}\right)$, and in $G_{4}, G_{8}$ and $G_{12}$ generations of inbreeding. IFR values for each inbreeding generation are also presented. OBS. and EXP. mean observed and expected, respectively.

\begin{tabular}{|c|c|c|c|c|c|c|c|}
\hline & \multicolumn{7}{|c|}{ Generations } \\
\hline & $\mathrm{G}_{0}$ & \multicolumn{2}{|c|}{$\mathrm{G}_{4}$} & \multicolumn{2}{|c|}{$\mathrm{G}_{8}$} & \multicolumn{2}{|c|}{$\mathrm{G}_{12}$} \\
\hline Karyotypes & OBS. & OBS. & EXP. & OBS. & EXP. & OBS. & EXP. \\
\hline $\mathrm{J}_{\mathrm{st}} / \mathrm{J}_{\mathrm{st}}$ & 0.036 & 0.267 & 0.189 & 0.273 & 0.234 & 0.250 & 0.253 \\
\hline $\mathrm{J}_{\mathrm{st}} / \mathrm{J}_{1}$ & 0.464 & 0.067 & 0.159 & 0.091 & 0.068 & l & 0.029 \\
\hline $\mathrm{J}_{1} / \mathrm{J}_{1}$ & 0.500 & 0.666 & 0.652 & 0.636 & 0.698 & 0.750 & 0.717 \\
\hline $\mathrm{U}_{\mathrm{st}} / \mathrm{U}_{\mathrm{st}}$ & 0.036 & I & 0.068 & l & 0.090 & I & 0.100 \\
\hline $\mathrm{U}_{\mathrm{st}} / \mathrm{U}_{\underline{1}+\underline{2}}$ & 0.072 & l & 0.051 & l & 0.022 & / & 0.009 \\
\hline $\mathrm{U}_{\mathrm{st}} / \mathrm{U}_{\underline{1+2+6}}$ & 0.036 & l & 0.019 & l & 0.008 & l & 0.003 \\
\hline
\end{tabular}




\begin{tabular}{|c|c|c|c|c|c|c|c|}
\hline $\mathrm{U}_{\mathrm{st}} / \mathrm{U}_{\underline{1+8}+\underline{2}}$ & 0.036 & l & 0.008 & / & 0.003 & / & 0.001 \\
\hline $\mathrm{U}_{\underline{1}+\underline{2}} / \mathrm{U}_{\underline{1}+\underline{2}}$ & 0.357 & 0.333 & 0.491 & 0.545 & 0.547 & 0.500 & 0.571 \\
\hline $\mathrm{U}_{\underline{1}+\underline{2}} / \mathrm{U}_{\underline{1+2+6}}$ & 0.321 & 0.466 & 0.102 & 0.455 & 0.044 & 0.500 & 0.019 \\
\hline $\mathrm{U}_{\underline{1}+\underline{2}} / \mathrm{U}_{\underline{1+8}+\underline{2}}$ & 0.072 & 0.067 & 0.043 & / & 0.018 & / & 0.008 \\
\hline $\mathrm{U}_{\underline{1+2+6}} / \mathrm{U}_{\underline{1+2+6}}$ & 0.036 & 0.067 & 0.146 & / & 0.188 & / & 0.201 \\
\hline $\mathrm{U}_{\underline{1+2+6}} / \mathrm{U}_{\underline{1+8}+\underline{2}}$ & / & 0.067 & 0.015 & / & 0.018 & I & 0.003 \\
\hline $\mathrm{U}_{\underline{1+8}+\underline{2}} / \mathrm{U}_{\underline{1+8}+\underline{2}}$ & 0.036 & / & 0.056 & / & 0.075 & I & 0.083 \\
\hline $\mathrm{E}_{\mathrm{st}} / \mathrm{E}_{\mathrm{st}}$ & / & 0.133 & 0.188 & 0.182 & 0.234 & 0.375 & 0.253 \\
\hline $\mathrm{E}_{\mathrm{st}} / \mathrm{E}_{\underline{1+2+9}}$ & 0.321 & 0.067 & 0.101 & / & 0.043 & I & 0.019 \\
\hline $\mathrm{E}_{\mathrm{st}} / \mathrm{E}_{8}$ & 0.214 & 0.133 & 0.054 & 0.091 & 0.023 & / & 0.010 \\
\hline $\mathrm{E}_{\underline{1+2}} / \mathrm{E}_{8}$ & 0.036 & / & 0,003 & / & 0.002 & / & $<0.001$ \\
\hline $\mathrm{E}_{\underline{1+2+9}} / \mathrm{E}_{\underline{1+2+9}}$ & 0.214 & 0.333 & 0.363 & 0.363 & 0.421 & 0.375 & 0.445 \\
\hline $\mathrm{E}_{\underline{1+2+9}} / \mathrm{E}_{\underline{1+2+9+12}}$ & / & 0.067 & 0.007 & / & 0.003 & I & 0.001 \\
\hline $\mathrm{E}_{\underline{1+2+9}} / \mathrm{E}_{8}$ & 0.143 & 0.200 & 0.094 & 0.091 & 0.040 & I & 0.017 \\
\hline
\end{tabular}




\begin{tabular}{|c|c|c|c|c|c|c|c|}
\hline $\mathrm{E}_{\underline{1+2+9+12}} / \mathrm{E}_{8}$ & 0.036 & I & 0.004 & / & 0.002 & / & $<0.001$ \\
\hline $\mathrm{E}_{8} / \mathrm{E}_{8}$ & 0.036 & 0.067 & 0.174 & 0.273 & 0.217 & 0.250 & 0.236 \\
\hline $\mathrm{O}_{\mathrm{st}} / \mathrm{O}_{\mathrm{st}}$ & / & 0.067 & 0.146 & 0.273 & 0.185 & 0.250 & 0.201 \\
\hline $\mathrm{O}_{\mathrm{st}} / \mathrm{O}_{\underline{3+4}}$ & 0.214 & 0.200 & 0.081 & 0.091 & 0.036 & / & 0.015 \\
\hline $\mathrm{O}_{\mathrm{st}} / \mathrm{O}_{\underline{3+4}+\underline{1}}$ & 0.071 & 0.067 & 0.025 & / & 0.011 & / & 0.005 \\
\hline $\mathrm{O}_{\mathrm{st}} / \mathrm{O}_{\underline{3+4}+\underline{6}}$ & 0.036 & 0.067 & 0.003 & l & 0.001 & 0.125 & $<0.001$ \\
\hline $\mathrm{O}_{\mathrm{st}} / \mathrm{O}_{\underline{3+4}+\underline{22}}$ & 0.107 & I & 0.019 & / & 0.008 & l & 0.003 \\
\hline $\mathrm{O}_{\underline{3+4}} / \mathrm{O}_{\underline{3+4}}$ & 0.214 & 0.200 & 0.363 & 0.273 & 0.421 & 0.375 & 0.445 \\
\hline $\mathrm{O}_{\underline{3+4}} / \mathrm{O}_{\underline{3+4}}+\underline{1}$ & 0.214 & 0.067 & 0.054 & l & 0.023 & l & 0.010 \\
\hline $\mathrm{O}_{\underline{3+4}} / \mathrm{O}_{\underline{3+4+8}}$ & I & 0.067 & 0.014 & 0.091 & 0.006 & l & 0.003 \\
\hline $\mathrm{O}_{\underline{3+4}} / \mathrm{O}_{\underline{3+4}}+\underline{22}$ & 0.071 & I & 0.040 & l & 0.017 & l & 0.007 \\
\hline $\mathrm{O}_{\underline{3+4}+\underline{1}} / \mathrm{O}_{\underline{3+4}+\underline{6}}$ & I & 0.067 & 0.002 & l & $<0.001$ & l & $<0.001$ \\
\hline $\mathrm{O}_{\underline{3+4}+\underline{1}} / \mathrm{O}_{\underline{3+4}}+\underline{22}$ & / & 0.067 & 0.012 & 0.091 & 0.005 & 0.125 & 0.002 \\
\hline $\mathrm{O}_{\underline{3+4}+\underline{5}} / \mathrm{O}_{\underline{3+4+8}}$ & 0.036 & I & $<0.001$ & l & $<0.001$ & l & $<0.001$ \\
\hline
\end{tabular}




$\begin{array}{lcccccc}\mathrm{O}_{\underline{3+4}+\underline{7}} / \mathrm{O}_{\underline{3+4}+\underline{7}} & / & 0.067 & <0.001 & 0.091 & <0.001 & 0.125 \\ \mathrm{O}_{\underline{3+4+8}} / \mathrm{O}_{\underline{3+4+8}} & / & / & 0.023 & / & 0.032 & /<0.001 \\ \mathrm{O}_{\underline{3+4+8}} / \mathrm{O}_{\underline{3+4}+\underline{22}} & 0.036 & / & 0.003 & / & <0.001 & / \\ \mathrm{O}_{\underline{3+4}+\underline{22}} / \mathrm{O}_{\underline{3+4}+\underline{22}} & / & 0.067 & 0.068 & 0.091 & 0.090 & /\end{array}$


Table 3. Chromosomal inversions and arrangements observed in the remaining lines of inbreeding process $\left(\mathrm{G}_{12}\right)$.

\begin{tabular}{|c|c|c|c|c|c|}
\hline \multirow[b]{2}{*}{ Inbred chromosomal lines } & \multicolumn{5}{|c|}{ Chromosomes } \\
\hline & A & $\mathrm{J}$ & $\mathrm{U}$ & E & $\mathrm{O}$ \\
\hline 1 & $\mathrm{~A}_{1}$ & $\mathrm{~J}_{\mathrm{st}}$ & $\mathrm{U}_{\underline{1}+\underline{2}}$ & $\mathrm{E}_{\underline{1+2+9}}$ & $\mathrm{O}_{\underline{3+4}+1} ; \mathrm{O}_{\underline{3+4}} \underline{22}$ \\
\hline 2 & $\mathrm{~A}_{1}$ & $\mathrm{~J}_{\mathrm{st}}$ & $\mathrm{U}_{\underline{1}+\underline{2}}$ & $\mathrm{E}_{\mathrm{st}}$ & $\mathrm{O}_{\mathrm{st}} ; \mathrm{O}_{\underline{3+4}+\underline{6}}$ \\
\hline 3 & $\mathrm{~A}_{\mathrm{st}}$ & $\mathrm{J}_{1}$ & $\mathrm{U}_{\underline{1}+\underline{2}}$ & $\mathrm{E}_{\mathrm{st}}$ & $\mathrm{O}_{\mathrm{st}}$ \\
\hline 4 & $\mathrm{~A}_{\mathrm{st}}$ & $\mathrm{J}_{1}$ & $\mathrm{U}_{\underline{1}+\underline{2}}$ & $\mathrm{E}_{8}$ & $\mathrm{O}_{\underline{3+4}}$ \\
\hline 5 & $\mathrm{~A}_{2}$ & $\mathrm{~J}_{1}$ & $\mathrm{U}_{\underline{1}+\underline{2}} ; \mathrm{U}_{\underline{1+2+6}}$ & $\mathrm{E}_{\underline{1+2+9}}$ & $\mathrm{O}_{\underline{3+4}}$ \\
\hline 6 & $\mathrm{~A}_{1}$ & $\mathrm{~J}_{1}$ & $\mathrm{U}_{\underline{1}+\underline{2}} ; \mathrm{U}_{\underline{1+2+6}}$ & $\mathrm{E}_{8}$ & $\mathrm{O}_{\underline{3+4}+\underline{7}}$ \\
\hline 7 & $\mathrm{~A}_{\mathrm{st}}$ & $\mathrm{J}_{1}$ & $\mathrm{U}_{\underline{1+2}} ; \mathrm{U}_{\underline{1+2+6}}$ & $\mathrm{E}_{\underline{1+2+9}}$ & $\mathrm{O}_{\mathrm{st}}$ \\
\hline 8 & $\mathrm{~A}_{\mathrm{st}}$ & $\mathrm{J}_{1}$ & $\mathrm{U}_{\underline{1}+\underline{2}} ; \mathrm{U}_{\underline{1+2+6}}$ & $\mathrm{E}_{\mathrm{st}}$ & $\mathrm{O}_{\underline{3+4}}$ \\
\hline
\end{tabular}

Segregating arrangements are denoted by “;”, symbol. 
Table 4. ANOVA analysis for fertility (number of arisen flies). Fixed factors are: temperature, chromosomal line and replicates. Bold $p$-values are significant.

\begin{tabular}{lcccc} 
Source of variation & d.f. & MS & F & $P$-value \\
\hline Temperature & 1 & 258.133 & 29.900 & $\mathbf{0 . 0 0 0}$ \\
Chrom. Line & 4 & 51.283 & 5.940 & $\mathbf{0 . 0 0 2}$ \\
Replicates & 2 & 10.133 & 1.170 & 0.328 \\
Error & 22 & 8.633 & & \\
& & & & \\
\hline
\end{tabular}


Table 5. ANOVA analysis for fertility (number of arisen flies) at $18^{\circ} \mathrm{C}$. Fixed factors are: chromosomal line and replicates. Bold p-values are significant.

\begin{tabular}{lcccc} 
Source of variation & d.f. & MS & F & $P$-value \\
& & & & \\
\hline Chrom. Line & 7 & 47.333 & 5.890 & $\mathbf{0 . 0 0 2}$ \\
Replicates & 2 & 10.792 & 1.340 & 0.293 \\
Error & 14 & 8.030 & & \\
& & & & \\
\hline
\end{tabular}


A

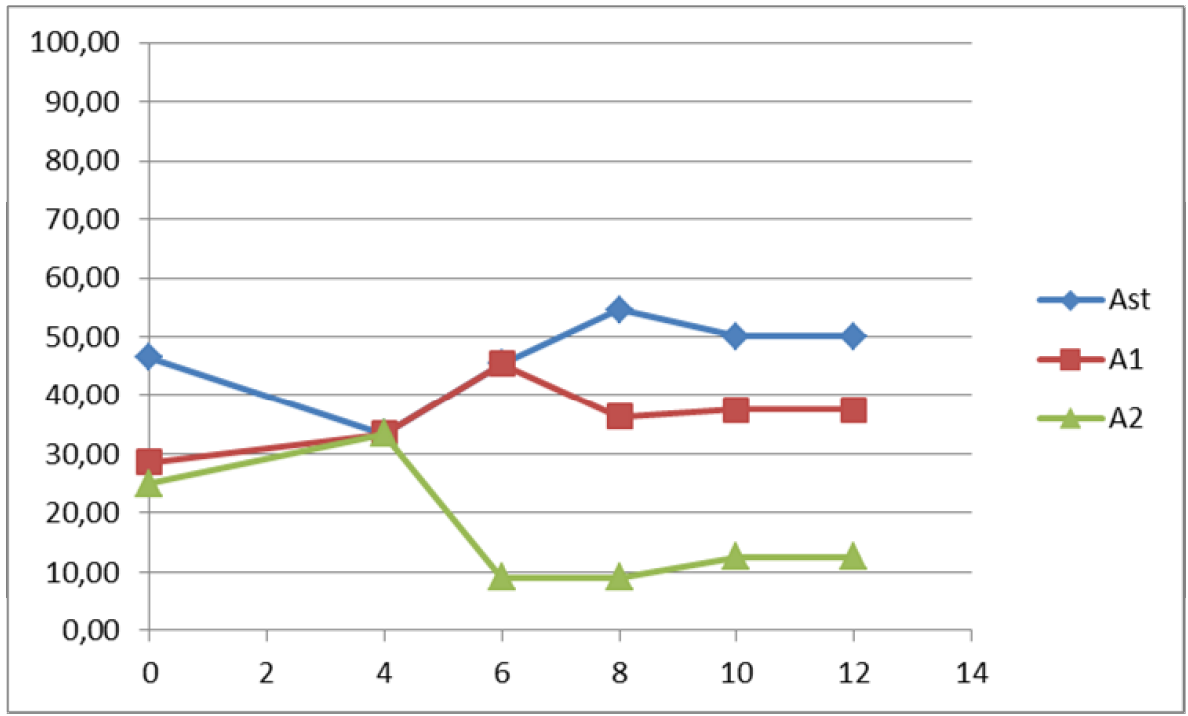

B

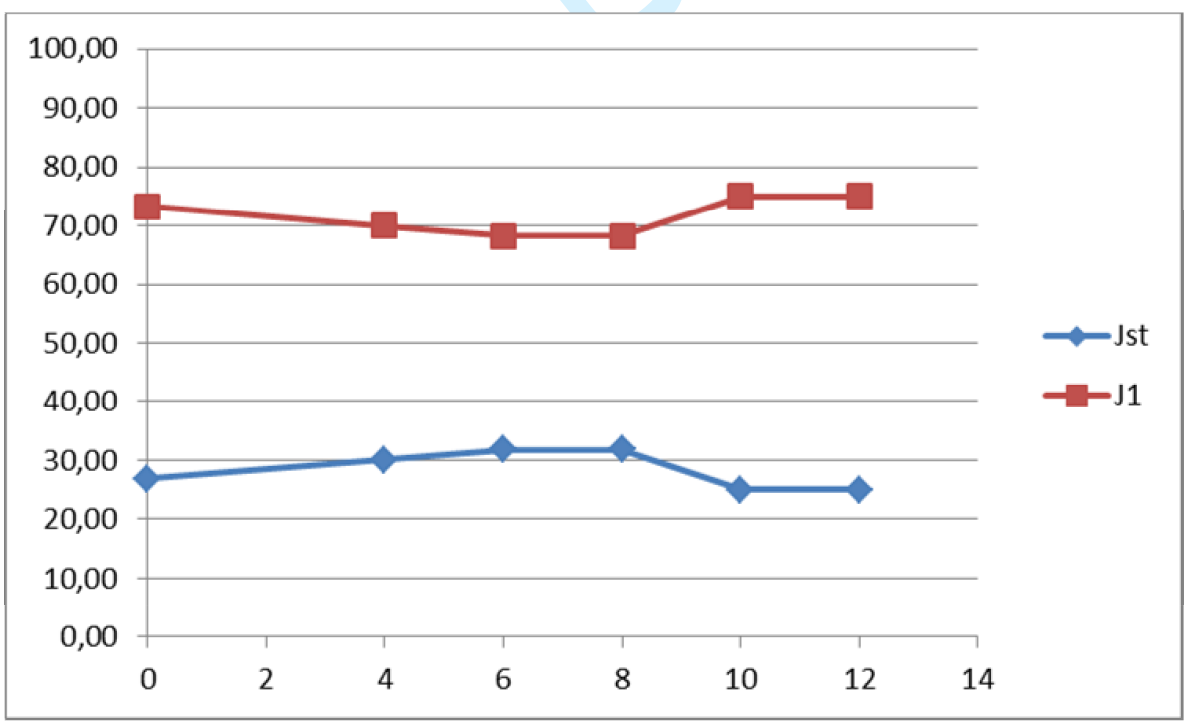


C

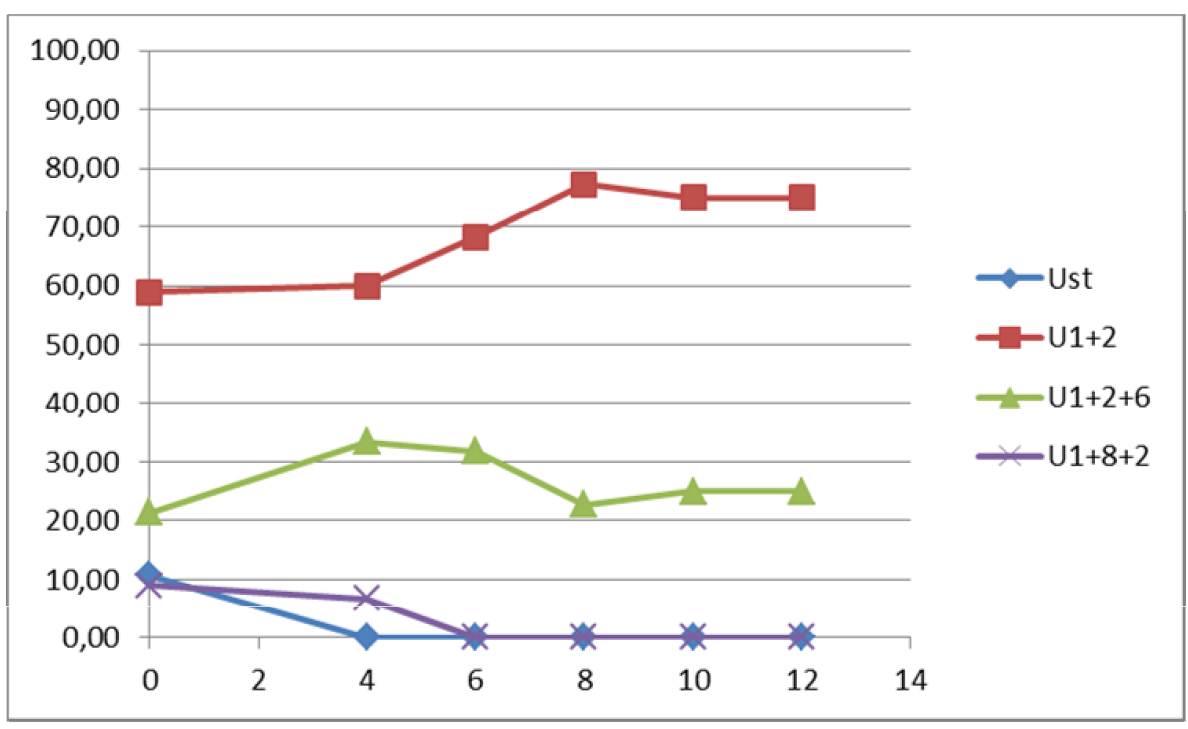

D

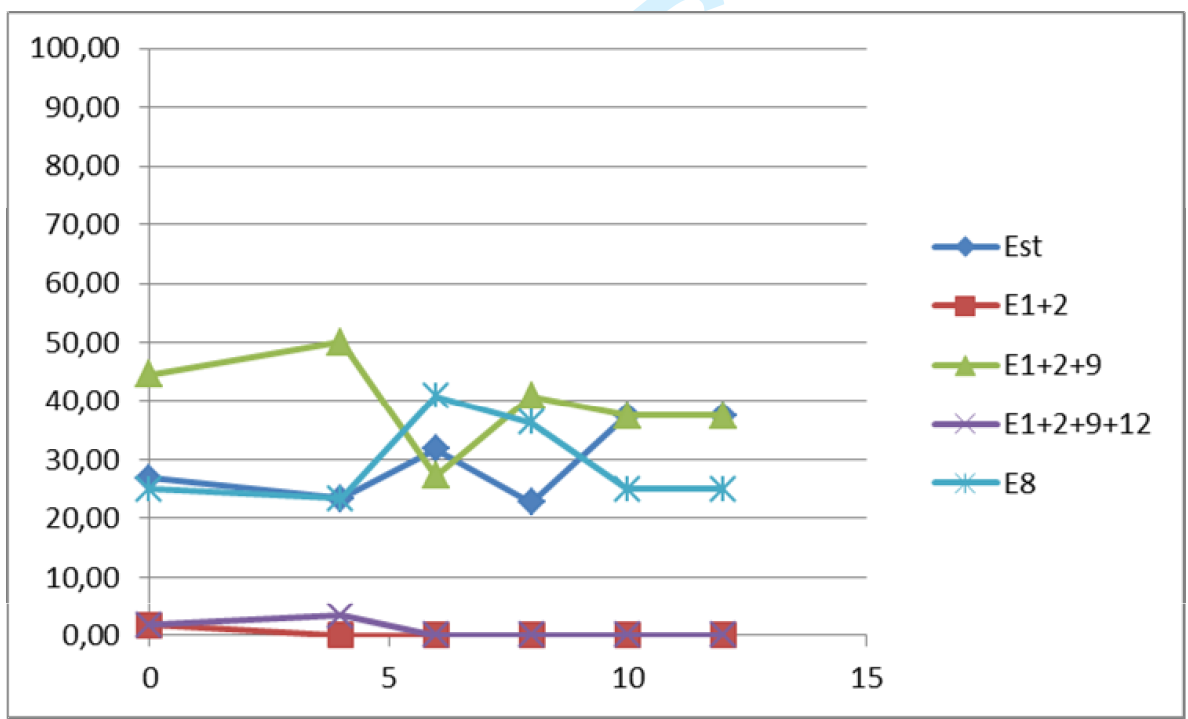


$\mathbf{E}$

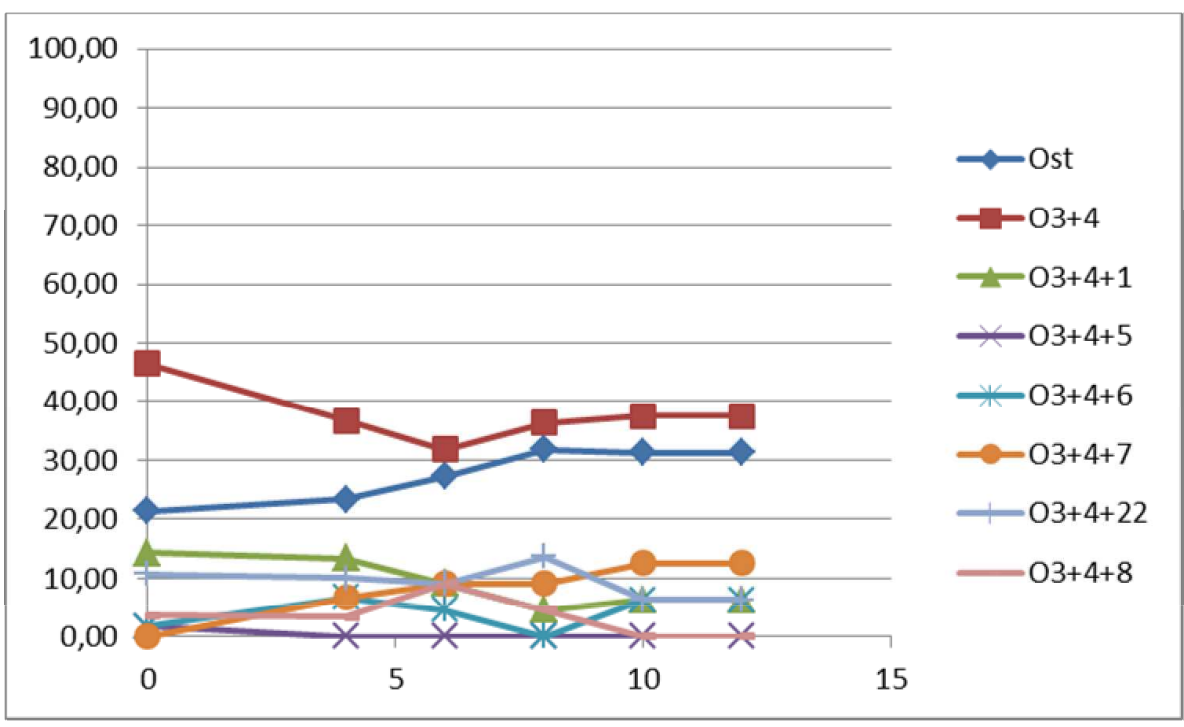

https://mc06.manuscriptcentral.com/genome-pubs 
Supplementary Table S1. Meteorological data for the Avala Mountain for days $30^{\text {th }}$ of May to $5^{\text {th }}$ of June 2011.

\begin{tabular}{ccccc}
\hline Days & Max. T $\left({ }^{\circ} \mathrm{C}\right)$ & Min. T $\left({ }^{\circ} \mathrm{C}\right)$ & Mean T $\left({ }^{\circ} \mathrm{C}\right)$ & Rainfall $(\mathrm{mm})$ \\
\hline 30. 05. 2011 & 26.1 & 14.0 & 21.7 & 0.3 \\
31. 05. 2011 & 29.0 & 18.3 & 23.0 & $/$ \\
01. 06. 2011 & 28.3 & 17.0 & 22.2 & $/$ \\
02. 06. 2011 & 26.7 & 16.7 & 19.8 & / \\
03. 06. 2011 & 26.3 & 17.3 & 22.3 & / \\
04. 06. 2011 & 29.1 & 17.0 & 23.9 & / \\
05. 06. 2011 & 29.8 & 19.0 & 25.5 & \\
\hline
\end{tabular}

Max. T and Min. T stand for maximum and minimum temperatures, respectively. 
Supplementary Table S2. Numbers of arising males and females from the different inbred line (using three replicates) reared at $13^{\circ} \mathrm{C}$.

\section{$\begin{array}{lll}\text { LINE } 1 & \text { LINE } 1 & \text { LINE } 1\end{array}$ \\ Replicate $1 \quad$ Replicate $2 \quad$ Replicate 3}

\begin{tabular}{|c|c|c|c|c|c|c|}
\hline Days after & number & number & number & number & number & number \\
\hline \multirow[t]{3}{*}{ initial crosses } & of & of & of & of & of & of \\
\hline & arising & arising & arising & arising & arising & arising \\
\hline & males & females & males & females & males & females \\
\hline 39 & 1 & / & / & / & / & / \\
\hline 40 & / & / & I & / & / & / \\
\hline 41 & / & / & 1 & / & / & / \\
\hline 42 & / & / & I & / & / & / \\
\hline 43 & / & / & / & / & / & / \\
\hline 44 & l & / & I & / & / & 1 \\
\hline 45 & / & / & / & / & / & / \\
\hline 46 & / & / & 2 & / & / & / \\
\hline 47 & / & 1 & / & / & / & / \\
\hline 48 & 1 & 1 & / & / & / & / \\
\hline 49 & / & / & 1 & / & / & / \\
\hline
\end{tabular}

$\begin{array}{lllllll}\text { Total } & 2 & 2 & 3 & 0 & 0 & 1\end{array}$




\begin{tabular}{|c|c|c|c|c|c|c|}
\hline \multirow{3}{*}{ Days after } & \multicolumn{2}{|c|}{ LINE 3} & \multicolumn{2}{|c|}{ LINE 3} & \multicolumn{2}{|c|}{ LINE 3} \\
\hline & \multicolumn{2}{|c|}{ Replicate 1} & \multicolumn{2}{|c|}{ Replicate 2} & \multicolumn{2}{|c|}{ Replicate 3} \\
\hline & number & number & number & number & number & number \\
\hline initial crosses & of & of & of & of & of & of \\
\hline & arising & arising & arising & arising & arising & arising \\
\hline & males & females & males & females & males & females \\
\hline 42 & 1 & 1 & / & 1 & 1 & 1 \\
\hline 43 & l & / & / & 1 & l & / \\
\hline 44 & / & / & / & / & l & / \\
\hline 45 & l & / & / & / & / & / \\
\hline 46 & / & / & l & / & / & / \\
\hline 47 & / & / & 1 & / & / & / \\
\hline 48 & / & / & 1 & / & / & / \\
\hline 49 & l & / & / & / & / & l \\
\hline 50 & / & / & / & / & 1 & / \\
\hline $51-53$ & l & l & l & / & / & / \\
\hline 54 & l & I & / & / & / & 1 \\
\hline Total & 0 & 1 & 0 & 1 & 1 & 1 \\
\hline
\end{tabular}




\begin{tabular}{|c|c|c|c|c|c|c|}
\hline \multirow{3}{*}{ Days after } & \multicolumn{2}{|c|}{ LINE 4} & \multicolumn{2}{|c|}{ LINE 4} & \multicolumn{2}{|c|}{ LINE 4} \\
\hline & \multicolumn{2}{|c|}{ Replicate 1} & \multicolumn{2}{|c|}{ Replicate 2} & \multicolumn{2}{|c|}{ Replicate 3} \\
\hline & number & number & number & number & number & number \\
\hline initial crosses & of & of & of & of & of & of \\
\hline & arising & arising & arising & arising & arising & arising \\
\hline & males & females & males & females & males & females \\
\hline 45 & 1 & 1 & / & l & I & I \\
\hline 46 & / & I & I & I & / & I \\
\hline 47 & 1 & I & / & / & / & l \\
\hline 48 & / & 1 & l & I & / & l \\
\hline 49 & l & / & l & / & / & / \\
\hline 50 & l & I & 1 & I & / & / \\
\hline 51 & / & / & / & / & / & l \\
\hline 52 & l & / & / & 1 & / & / \\
\hline 53 & / & / & / & I & / & 1 \\
\hline Total & 2 & 2 & 0 & 1 & 0 & 1 \\
\hline
\end{tabular}




\begin{tabular}{|c|c|c|c|c|c|c|}
\hline \multirow{3}{*}{$\begin{array}{l}\text { Days after } \\
\end{array}$} & \multicolumn{2}{|c|}{ LINE 5} & \multicolumn{2}{|c|}{ LINE 5} & \multicolumn{2}{|c|}{ LINE 5} \\
\hline & \multicolumn{2}{|c|}{ Replicate 1} & \multicolumn{2}{|c|}{ Replicate 2} & \multicolumn{2}{|c|}{ Replicate 3} \\
\hline & number & number & number & number & number & number \\
\hline initial crosses & of & of & of & of & of & of \\
\hline & arising & arising & arising & arising & arising & arising \\
\hline & males & females & males & females & males & females \\
\hline 42 & 1 & 1 & I & I & I & I \\
\hline 43 & / & / & / & 1 & / & / \\
\hline 44 & / & / & / & / & / & / \\
\hline 45 & / & / & / & / & / & / \\
\hline 46 & / & / & I & / & / & / \\
\hline 47 & 1 & / & 1 & / & / & / \\
\hline Total & 2 & 0 & 0 & 1 & 0 & 0 \\
\hline
\end{tabular}




\section{LINE $6 \quad$ LINE $6 \quad$ LINE 6 \\ Replicate $1 \quad$ Replicate $2 \quad$ Replicate 3}

\begin{tabular}{|c|c|c|c|c|c|c|}
\hline Days after & number & number & number & number & number & number \\
\hline \multirow[t]{3}{*}{ initial crosses } & of & of & of & of & of & of \\
\hline & arising & arising & arising & arising & arising & arising \\
\hline & males & females & males & females & males & females \\
\hline 47 & 3 & I & l & / & l & / \\
\hline 48 & 1 & 1 & / & / & / & / \\
\hline 49 & 1 & / & 1 & / & / & / \\
\hline 50 & 1 & 1 & l & / & / & 1 \\
\hline 51 & 1 & 3 & I & / & / & / \\
\hline 52 & 1 & / & 1 & / & / & / \\
\hline 53 & / & 1 & / & l & l & / \\
\hline 54 & l & / & l & 1 & / & / \\
\hline 55 & / & / & l & / & l & / \\
\hline 56 & / & 1 & l & / & I & l \\
\hline
\end{tabular}

Total

8

7

1

0

1 
Supplementary Table S3. Numbers of arising males and females from the different inbred line (using three replicates) reared at $18^{\circ} \mathrm{C}$.

\section{$\begin{array}{lll}\text { LINE } 1 & \text { LINE } 1 & \text { LINE } 1\end{array}$ \\ $\begin{array}{lll}\text { Replicate } 1 & \text { Replicate } 2 & \text { Replicate } 3\end{array}$}

Days after number number number number number number initial crosses of of of of of arising arising arising arising arising arising males females males females males females

\begin{tabular}{lllllll}
25 & 1 & $/$ & $/$ & $/$ & 1 & $/$ \\
26 & 3 & $/$ & 1 & 1 & 2 & $/$ \\
27 & $/$ & 1 & 1 & 1 & $/$ & $/$ \\
28 & $/$ & $/$ & 1 & 1 & 1 & 3 \\
29 & $/$ & $/$ & $/$ & $/$ & $/$ & $/$ \\
30 & $/$ & $/$ & 1 & $/$ & $/$ & $/$ \\
31 & $/$ & $/$ & 1 & $/$ & $/$ & $/$ \\
32 & $/$ & 1 & $/$ & $/$ & $/$ & \\
\hline
\end{tabular}

$\begin{array}{lllllll}\text { Total } & 4 & 2 & 5 & 3 & 4 & 3\end{array}$




\begin{tabular}{|c|c|c|c|c|c|c|}
\hline \multirow{3}{*}{ Days after } & \multicolumn{2}{|c|}{ LINE 2} & \multicolumn{2}{|c|}{ LINE 2} & \multicolumn{2}{|c|}{ LINE 2} \\
\hline & \multicolumn{2}{|c|}{ Replicate 1} & \multicolumn{2}{|c|}{ Replicate 2} & \multicolumn{2}{|c|}{ Replicate 3} \\
\hline & number & number & number & number & number & number \\
\hline initial crosses & of & of & of & of & of & of \\
\hline & arising & arising & arising & arising & arising & arising \\
\hline & males & females & males & females & males & females \\
\hline 26 & 1 & / & I & 1 & 1 & 1 \\
\hline 27 & / & / & 3 & 2 & 1 & / \\
\hline 28 & / & / & 3 & 3 & 1 & 1 \\
\hline 29 & / & / & / & / & 1 & l \\
\hline 30 & / & / & / & / & / & 1 \\
\hline 31 & / & / & 1 & / & / & 1 \\
\hline 32 & 1 & / & 1 & / & / & / \\
\hline 33 & / & 1 & / & / & / & / \\
\hline Total & 1 & 1 & 6 & 6 & 3 & 3 \\
\hline
\end{tabular}




\begin{tabular}{|c|c|c|c|c|c|c|}
\hline \multirow{3}{*}{$\begin{array}{l}\text { Days after } \\
\end{array}$} & \multicolumn{2}{|c|}{ LINE 3} & \multicolumn{2}{|c|}{ LINE 3} & \multicolumn{2}{|c|}{ LINE 3} \\
\hline & \multicolumn{2}{|c|}{ Replicate 1} & \multicolumn{2}{|c|}{ Replicate 2} & \multicolumn{2}{|c|}{ Replicate 3} \\
\hline & number & number & number & number & number & number \\
\hline initial crosses & of & of & of & of & of & of \\
\hline & arising & arising & arising & arising & arising & arising \\
\hline & males & females & males & females & males & females \\
\hline 24 & 1 & 1 & 1 & 1 & 1 & I \\
\hline 25 & / & l & l & I & l & / \\
\hline 26 & / & / & / & / & / & 1 \\
\hline 27 & 1 & / & 1 & / & 1 & I \\
\hline 28 & 4 & 1 & / & 1 & 1 & / \\
\hline 29 & / & 2 & 1 & 1 & 1 & 1 \\
\hline 30 & / & 1 & l & / & 1 & l \\
\hline 31 & / & / & l & / & / & l \\
\hline 32 & / & / & l & / & / & 1 \\
\hline 33 & / & / & l & / & / & l \\
\hline 34 & I & / & l & l & l & l \\
\hline 35 & / & / & / & / & / & l \\
\hline 36 & / & l & l & / & I & l \\
\hline 37 & I & 1 & I & I & / & 1 \\
\hline 38 & 1 & 1 & I & I & 1 & 1 \\
\hline Total & 5 & 4 & 3 & 2 & 4 & 4 \\
\hline
\end{tabular}




\section{LINE $4 \quad$ LINE $4 \quad$ LINE 4 \\ Replicate $1 \quad$ Replicate $2 \quad$ Replicate 3}

\begin{tabular}{lcccccc}
\hline Days after & number & number & number & number & number & number \\
initial crosses & of & of & of & of & of & of \\
& arising & arising & arising & arising & arising & arising \\
& males & females & males & females & males & females \\
& 1 & $/$ & $/$ & $/$ & $/$ & $/$ \\
\hline 25 & $/$ & $/$ & 1 & $/$ & $/$ & $/$ \\
26 & $/$ & $/$ & 1 & $/$ & $/$ & 2 \\
27 & $/$ & $/$ & 1 & 2 & 1 & $/$ \\
28 & $/$ & 1 & $/$ & $/$ & $/$ & $/$ \\
29 & 2 & 3 & $/$ & 1 & 1 & $/$ \\
30 & $/$ & 1 & $/$ & $/$ & $/$ & 1 \\
31 & $/$ & $/$ & $/$ & $/$ & $/$ & $/$ \\
32 & $/$ & $/$ & $/$ & $/$ & 1 & $/$ \\
33 & / & $/$ & $/$ & $/$ & $/$ & $/$ \\
34 & & & $/$ & $/$ & $/$ & 1 \\
35 & & & & & & \\
\hline
\end{tabular}

Total

35

3

3

3

4 


\begin{tabular}{|c|c|c|c|c|c|c|}
\hline \multirow{3}{*}{$\begin{array}{l}\text { Days after } \\
\end{array}$} & \multicolumn{2}{|c|}{ LINE 5} & \multicolumn{2}{|c|}{ LINE 5} & \multicolumn{2}{|c|}{ LINE 5} \\
\hline & \multicolumn{2}{|c|}{ Replicate 1} & \multicolumn{2}{|c|}{ Replicate 2} & \multicolumn{2}{|c|}{ Replicate 3} \\
\hline & number & number & number & number & number & number \\
\hline initial crosses & of & of & of & of & of & of \\
\hline & arising & arising & arising & arising & arising & arising \\
\hline & males & females & males & females & males & females \\
\hline 26 & 1 & 1 & 1 & I & I & 1 \\
\hline 27 & 1 & 1 & 3 & 1 & / & / \\
\hline 28 & 1 & / & / & / & 2 & / \\
\hline 29 & l & 1 & / & / & 1 & 2 \\
\hline 30 & 1 & / & 1 & / & / & / \\
\hline 31 & / & / & 1 & 1 & / & / \\
\hline Total & 3 & 2 & 5 & 2 & 3 & 2 \\
\hline
\end{tabular}




\section{$\begin{array}{lll}\text { LINE } 6 & \text { LINE } 6 & \text { LINE } 6\end{array}$ \\ Replicate $1 \quad$ Replicate $2 \quad$ Replicate 3}

\begin{tabular}{|c|c|c|c|c|c|c|}
\hline Days after & number & number & number & number & number & number \\
\hline \multirow[t]{3}{*}{ initial crosses } & of & of & of & of & of & of \\
\hline & arising & arising & arising & arising & arising & arising \\
\hline & males & females & males & females & males & females \\
\hline 27 & 1 & 1 & / & 1 & I & 1 \\
\hline 28 & 1 & / & 1 & 1 & / & / \\
\hline 29 & 1 & 2 & 5 & 2 & 2 & 1 \\
\hline 30 & 1 & 2 & 7 & 3 & 2 & 1 \\
\hline 31 & 1 & 1 & 1 & / & 3 & / \\
\hline 32 & 1 & / & I & / & 1 & 3 \\
\hline 33 & / & / & / & 1 & / & / \\
\hline $34-36$ & / & l & / & / & / & / \\
\hline 37 & / & l & / & / & 1 & / \\
\hline
\end{tabular}

$\begin{array}{llllllll}\text { Total } & 6 & 6 & 13 & 7 & 9 & 5\end{array}$




\begin{tabular}{|c|c|c|c|c|c|c|}
\hline \multirow{2}{*}{$\begin{array}{l}\text { Days after } \\
\text { initial crosses }\end{array}$} & \multicolumn{2}{|c|}{ LINE 7} & \multicolumn{2}{|c|}{ LINE 7} & \multicolumn{2}{|c|}{ LINE 7} \\
\hline & \multicolumn{2}{|c|}{ Replicate 1} & \multicolumn{2}{|c|}{ Replicate 1} & \multicolumn{2}{|c|}{ Replicate 1} \\
\hline Days after & number & number & number & number & number & number \\
\hline initial crosses & of & of & of & of & of & of \\
\hline & arising & arising & arising & arising & arising & arising \\
\hline & males & females & males & females & males & females \\
\hline 25 & I & / & 1 & 1 & 1 & / \\
\hline 26 & / & / & / & / & / & / \\
\hline 27 & / & / & / & / & / & / \\
\hline 28 & 2 & / & 2 & / & / & / \\
\hline 29 & 2 & / & / & / & / & / \\
\hline 30 & 2 & / & 1 & / & / & / \\
\hline 31 & / & / & I & / & / & / \\
\hline 32 & / & / & 1 & 1 & / & / \\
\hline 33 & / & / & / & 1 & / & / \\
\hline $34-36$ & / & / & / & / & I & / \\
\hline 37 & / & 1 & / & / & / & / \\
\hline Total & 6 & 1 & 3 & 3 & 0 & 0 \\
\hline
\end{tabular}




\begin{tabular}{|c|c|c|c|c|c|c|}
\hline \multirow{3}{*}{ Days after } & \multicolumn{2}{|c|}{ LINE 8} & \multicolumn{2}{|c|}{ LINE 8} & \multicolumn{2}{|c|}{ LINE 8} \\
\hline & \multicolumn{2}{|c|}{ Replicate 1} & \multicolumn{2}{|c|}{ Replicate 2} & \multicolumn{2}{|c|}{ Replicate 3} \\
\hline & number & number & number & number & number & number \\
\hline initial crosses & of & of & of & of & of & of \\
\hline & arising & arising & arising & arising & arising & arising \\
\hline & males & females & males & females & males & females \\
\hline 26 & / & 3 & l & I & l & I \\
\hline 27 & / & / & l & l & l & l \\
\hline 28 & / & / & l & l & l & / \\
\hline 29 & I & / & l & / & l & l \\
\hline 30 & / & / & 1 & / & l & I \\
\hline 31 & / & l & 1 & / & / & l \\
\hline 32 & / & I & / & 1 & l & l \\
\hline Total & 0 & 3 & 0 & 1 & 0 & 0 \\
\hline
\end{tabular}

